\title{
Liver Remnant Regeneration in Donors After Living Donor Liver Transplantation: Long-Term Follow-Up Using CT and MR Imaging
}

\section{Regeneration des verbliebenen Lebergewebes bei Spendern nach Leberlebendspende: Langzeitverlaufskontrollen mittels CT und MRT}

Authors

Affiliations
T. Klink $k^{1,3}$, P. Simon ${ }^{2,3}$, C. Knopp 3 , H. Ittrich ${ }^{3}$, L. Fischer ${ }^{4}$, G. Adam³ ${ }^{3}$, A. Koops ${ }^{3}$

Diagnostic, Interventional, and Pediatric Radiology, INSELSPITAL - Bern University Hospital, Bern

Department of Radiology, Neuroradiology, Sonography and Nuclearmedicine, Merciful Brethren Hospital, Trier

Diagnostic and Interventional Radiology, University Medical Center Hamburg Eppendorf, Hamburg

Department of Hepatobiliary Surgery und Transplant Surgery, University Medical Center Hamburg-Eppendorf, Hamburg
Key words

- living donor liver

transplantation

- MR imaging

- CT spiral

- donor safety

- long-term follow-up

- liver received 28.5.2013

accepted 23.9.2013

\section{Bibliography}

DOI http://dx.doi.org/ 10.1055/s-0033-1355894

Published online: 17.12.2013

Fortschr Röntgenstr 2014; 186:

598-605 @ Georg Thieme

Verlag KG Stuttgart · New York · ISSN 1438-9029

\section{Correspondence}

Dr. Thorsten Klink

Inselspital - Bern University

Hospital

Universitätsinstitut für

Diagnostische, Interventionelle und Pädiatrische Radiologie

Freiburgstrasse 10

$\mathrm{CH}-3010$ Bern

Schweiz

Tel.: ++41/316329107

Fax: $++41 / 316324874$

thorsten.klink@insel.ch

\section{Zusammenfassung}

$\nabla$

Ziel: Das Ziel dieser Studie war, die Regeneration und die Aufrechterhaltung des verbliebenen Lebervolumens sowie das Auftreten von Komplikationen im Langzeitverlauf bei Spendern nach Leberlebendspende mittels CT und MRT zu überprüfen.

Material und Methoden: In die retrospektive Studie wurden 47 Personen mit einem mittleren Alter von 33,5 Jahren eingeschlossen, die Lebergewebe gespendet hatten und für die Verlaufsbildgebung zur Verfügung standen. Kontrastverstärkte CT- und MRT-Untersuchungen wurden im Rahmen der Routinenachsorge angefertigt. Die prä- und postoperativen Bilder wurden durch zwei Beobachter im Hinblick auf die präoperative Anatomie und pathologische Befunde evaluiert. Organvolumina wurden manuell anhand kontrastverstärkter Bilder in portalvenöser Phase gemessen, und potentielle postoperatove Komplikationen wurden dokumentiert. Die Regeneration des verbliebenen Lebergewebes wurde durch Vergleich der prä- und postoperativen Volumina evaluiert.

Ergebnisse: Die Verlaufskontrollen erfolgten über einen mittleren Zeitraum von 22,4 Monaten (1 84 Monate), wobei 47 präoperative und 89 Verlaufsuntersuchungen zur Verfügung standen. Die Volumina des verbliebenen Lebergewebes betrugen nach Spende des rechten Leberlappens (RLL) $522,0 \mathrm{ml}( \pm 144,0 ; 36,1 \% ; \mathrm{n}=18)$, nach links-lateraler Sektion (LLS) $1121,7 \mathrm{ml}( \pm 212,8 ; 79,9 \%$; $\mathrm{n}=24$ ) und nach Spende des linken Leberlappens (LLL) $1181,5 \mathrm{ml}( \pm 279,5 ; 72,0 \% ; n=5)$. Nach 12 Monaten betrugen die verbliebenen Lebervolumina $87,3 \%$ (RLL; $\pm 11,8 ; \mathrm{n}=11$ ), $95,0 \%$ (LS; $\pm 11,6 ; n=18)$ und $80,1 \%(L L L ; \pm 2,0 ; n=2)$ der präoperativen Volumina. Das verbliebene Lebergewebes regenerierte zügig, wobei ein Volumenanteil von $80 \%$ des präoperativen Volumens über den gesamten Nachsorgezeitraum beobachtet

\section{Abstract \\ $\nabla$}

Purpose: To assess liver remnant volume regeneration and maintenance, and complications in the long-time follow-up of donors after living donor liver transplantation using CT and MRI.

Materials and Methods: 47 donors with a mean age of 33.5 years who donated liver tissue for transplantation and who were available for follow-up imaging were included in this retrospective study. Contrast-enhanced CT and MR studies were acquired for routine follow-up. Two observers evaluated pre- and postoperative images regarding anatomy and pathological findings. Volumes were manually measured on contrast-enhanced images in the portal venous phase, and potential postoperative complications were documented. Preand postoperative liver volumes were compared for evaluating liver remnant regeneration.

Results: 47 preoperative and 89 follow-up studies covered a period of 22.4 months (range: $1-84$ ). After right liver lobe (RLL) donation, the mean liver remnant volume was $522.0 \mathrm{ml}( \pm 144.0 ; 36.1 \%$; $\mathrm{n}=18$ ), after left lateral section (LLS) donation $1,121.7 \mathrm{ml}( \pm 212.8 ; 79.9 \% ; n=24)$, and after left liver lobe (LLL) donation $1,181.5 \mathrm{ml}( \pm 279.5$; $72.0 \% ; n=5)$. Twelve months after donation, the liver remnant volume were $87.3 \%$ (RLL; \pm 11.8 ; $\mathrm{n}=11$ ), $95.0 \%(\mathrm{LS} ; \pm 11.6 ; \mathrm{n}=18$ ), and $80.1 \%$ (LLL; \pm 2.0 ; $n=2 \mathrm{LLL}$ ) of the preoperative total liver volume. Rapid initial regeneration and maintenance at $80 \%$ of the preoperative liver volume were observed over the total follow-up period. Minor postoperative complications were found early in 4 patients. No severe or late complications or mortality occurred.

Conclusion: Rapid regeneration of liver remnant volumes in all donors and volume maintenance over the long-term follow-up period of up to 84 months without severe or late complications are important observations for assessing the safety of LDLT donors. 
wurde. Leichtgradige Komplikationen wurden frühzeitig bei 4 Patienten festgestellt. Es wurden jedoch keine schwergradigen oder spät auftretenden Komplikationen gefunden.

Schlussfolgerung: Die zügige Regeneration des verbliebenen Lebervolumens bei Leberlebendspendern, dessen Aufrechterhaltung über den gesamten Nachsorgezeitraum von max. 84 Monaten und das Ausbleiben schwerer oder später Komplikationen sind wichtige Beobachtungen, um die Sicherheit potentieller Leberlebendspender abzuschätzen.

Kernaussage: Bei Leberlebendspendern regenerierte das verbliebene Lebergewebe zügig, wobei die Organvolumnia über den gesamten Nachsorgezeitraum von bis zu 84 Monaten aufrecht erhalten wurden und keine schwerwiegenden oder späten Komplikationen auftraten.

\section{Introduction}

Liver transplantation, as introduced in 1963, is today an established procedure in the treatment of end-stage liver disease [1]. Due to the persisting lack of post-mortem organs, living donor liver transplantation (LDLT) is of increasing importance [2]. LDLT has several advantages for the recipient: Reduced waiting time for transplantation, optimal recipient preparation, elective schedule, and a superior quality of transplant tissue [3]. In Europe and North America, transplant centers perform LDLT in only less than $5 \%$ of cases, while LDLT finds much more acceptance in Asian countries [2, 4]. The evaluation and information of donors about the LDLT procedure, safety and potential complications during and after the operation are important steps for LDLT planning, and help donors in the process of decision-making [5, 6].

The regenerative potential of the future liver remnant (FLR) in the donor is key for LDLT. It is influenced by graft size, donor age, and presence of the middle hepatic vein, and has been evaluated in short-term follow-up studies [7, 8]. It has been shown that the FLR has the strongest regenerative potential within the first weeks after donation $[7,9,10]$.

Computed tomography (CT) and magnetic resonance imaging (MRI) play important roles in the evaluation of liver donors. Imaging delivers important anatomical information such as liver volume, liver morphology, and vascular or biliary variants. Hepatobiliary and other pathologies are detectable, and severe disorders are precluded prior to surgery. Postoperative imaging is routinely used for detecting complications and for evaluating the regeneration of the liver remnant. Before and after LDLT, volumetric analyses of liver tissue are an integral part of CT and MR imaging. Preoperative volumetry assesses both the potential dimensions of transplantable liver grafts and the dimensions of future liver remnants in donors. Postoperative volumetry documents the regrowth of the liver remnant, thus indicating liver regeneration during follow-up [11]. Several studies have shown that volumetric analyses of liver segments, which can be manually, semi-automatically, and automatically performed, correlate well with intraoperatively measured weights of corresponding organ parts [12]. Long-term volumetric assessment of liver remnant regeneration in donors is important for ensuring the safety of this "healthy" patient group, but has not been well evaluated so far. The aim of this study was to observe the volume regeneration of remaining liver tissue in donors after LDLT over a long-term period (up to 7 years) utilizing CT and MR imaging. Furthermore, follow-up imaging of donors was evaluated regarding early, late, and persisting complications after liver donation.
Key Points: Liver remnant volumes of LDLT donors rapidly regenerated after donation and volumes were maintained over the long-term follow-up period of up to 84 months without severe or late complications.

Citation Format:

- Klink T, Simon P, Knopp C et al. Liver Remnant Regeneration in Donors After Living Donor Liver Transplantation: Long-Term Follow-Up Using CT and MR Imaging. Fortschr Röntgenstr 2014; 186: 598-605

\section{Materials and methods}

$\nabla$

\section{Study design}

47 subjects (female, 21 ; male, 26) with a mean age of 33.5 years (range, 21 - 59 years) who donated liver tissue for transplantation between 1997 and 2007 were included in this retrospective study after institutional review board approval.

Inclusion criteria:

- Female and male donors

- Minimum age of 18 years

- Participation in the locally offered follow-up program after transplantation

- Preoperative MRI and/or CT scan of the abdomen

- At least one postoperative MRI and/or CT scan of the abdomen Exclusion criteria:

- Patient age $<18$ years

- Loss to follow-up prior to postoperative abdominal CT or MRI scanning

- Patients with contraindications for both CT and MRI

\section{Imaging}

CT imaging

CT imaging of the upper abdomen was performed with a 4,16 , or 64-MSCT scanner (Philips MX 8000, Brilliance 16, or Brilliance 64; Philips Healthcare, Best, The Netherlands). The following scan parameters were set: Tube current: $120 \mathrm{kV}$; tube current time product: $150-300 \mathrm{mAs}$; collimation: $4 / 16 \times 0.75 \mathrm{~mm}$ and $64 \times 0.625 \mathrm{~mm}$, respectively; gantry rotation time: $0.5 / 0.75 \mathrm{~s}$; pitch: $0.875 / 0.95$. Preoperative images were acquired before and in the arterial, portal venous and late equilibrium phase after contrast material injection. $120 \mathrm{ml}$ Imeprol (300 mg iodine/ml; Imeron $300 \mathrm{M}$, Bracco, Constance, Germany) were automatically injected intravenously at a flow rate of $3.0 \mathrm{ml} / \mathrm{s}$. Postoperative images were acquired during the portal venous phase (delay, $90 \mathrm{~s}$ ). Images were continuously reconstructed on the axial plane with a slice thickness of $5.0 \mathrm{~mm}$ and $\mathrm{z}$-axis coverage between the diaphragm and the iliac crest.

\section{MR imaging}

MRI was performed with a $1.5 \mathrm{~T}$ whole-body scanner (Achieva, Philips Healthcare) using a dedicated 4-channel flexible abdomen surface coil. The standard scan protocol included dynamic contrast-enhanced imaging, which was used for volumetry. T1w, fat-suppressed, fast field (T1-FFE) echo sequences were acquired using the following parameters: time of repetition (TR): $198 \mathrm{~ms}$; time of echo (TE): $4.6 \mathrm{~ms}$; flip angle: $80^{\circ}$, acquisition 
matrix: $256 \times 240$; slice thickness: $5 \mathrm{~mm}$; and field of view: $375 \times 262$. Gadolinium-DTPA (Magnevist, BayerHealthcare, Berlin, Germany) was injected automatically with $0.1 \mathrm{mmol} / \mathrm{kg}$ body-weight i. v. at a flow rate of $2.0 \mathrm{ml} / \mathrm{s}$ followed by $20 \mathrm{ml}$ saline chaser. Contrast-enhanced images were acquired in the native, arterial, portal venous, venous, and late equilibrium phase.

\section{Image evaluation}

Images were reviewed in consensus by two radiologists with 5 and 13 years of liver imaging experience on a standard PACS workstation (Centricity PACS-IW, GE Healthcare, Barrington, IL, USA) regarding the preoperative liver anatomy, pre- and postoperative liver volumes, and postoperative complications.

\section{Preoperative imaging}

Preoperative imaging included thorough evaluation of the individual donor liver anatomy. Normal and variable findings of the arterial, portal venous, and venous system, as well as of the biliary system were evaluated and described. Pathological findings and focal hepatic abnormalities were documented. Furthermore, volumes of the total liver, the potential transplant graft, and the future liver remnant were measured.

\section{Volume measurements}

Liver volumetry was performed on axial contrast-enhanced images in the portal venous phase using Osirix software, version 5.0 [13]. On preoperative images, the total liver volume, the graft volume, and the future liver remnant volume were measured. On postoperative images, the liver remnant volume was measured. Volumes of these liver sections were calculated using the "ROI volume" tool. The contours of the liver sections were manually outlined by free-hand drawn regions of interest (ROI) on each axial slice, as demonstrated in 0 Fig. 1. The manual delineation of the liver section borders was in accordance with the liver segment borders defined by Couinaud et al. [14]. The diaphragm, the gall bladder, and the left and right portal vein were excluded. The software automatically calculated the approximate volume of the selected liver tissue from the delineated cross-sectional areas and the slice thickness.
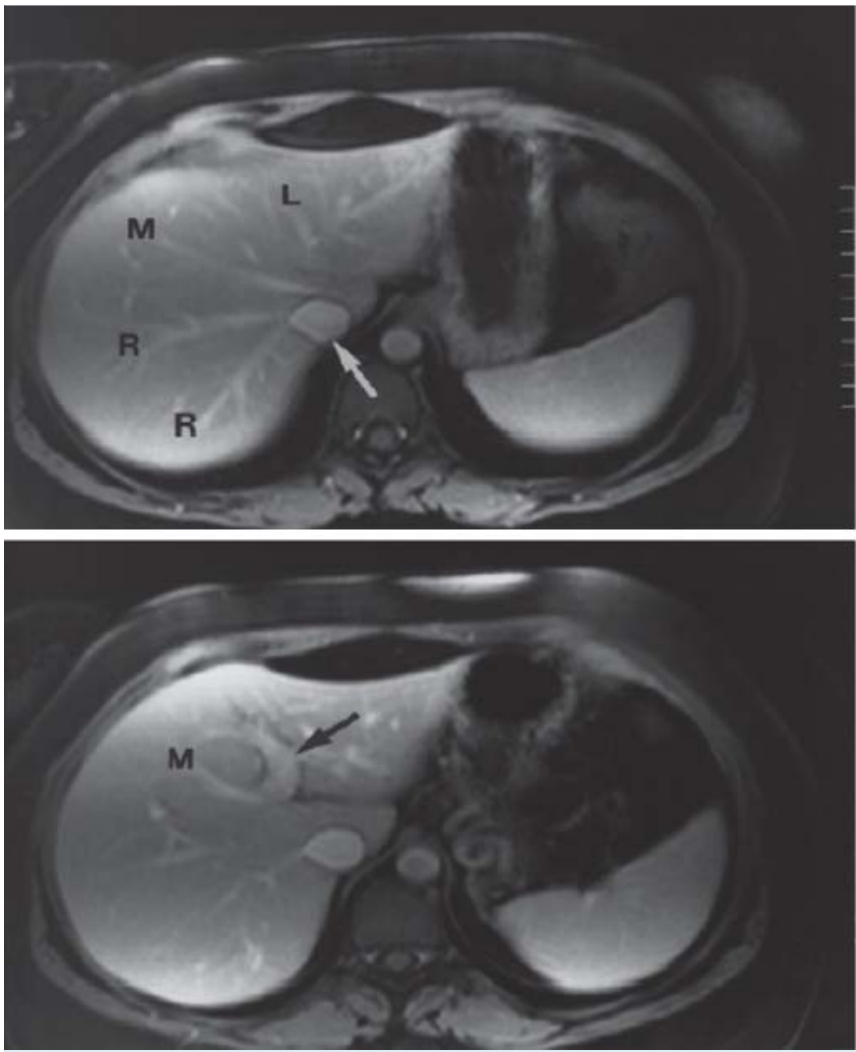

Fig. 1 Axial, fat-saturated, and contrast-enhanced T1w MR images demonstrate the liver segmentation technique for volumetry. The upper images were obtained at a more cranial level than the lower images. The inferior vena cava (white arrow, upper left image) and the left intrahepatic portal vein (black arrow, lower left image) were excluded from volume measurements (right images). Liver segments were defined according to Couinaud et al. [14]. Freehand region-of-interest contours included the right liver lobe (R, liver segments V, VI, VII, VIII), the left lateral liver segments (L, liver segments II and III), the caudate lobe (C, liver segment I), and the liver segments IVa and IVb (M). Donation of the right lobe included "R", left lateral section included "L", and left lobe donation included "L", "M", and " $C$ " ( $C$, in 3 of 5 donors).
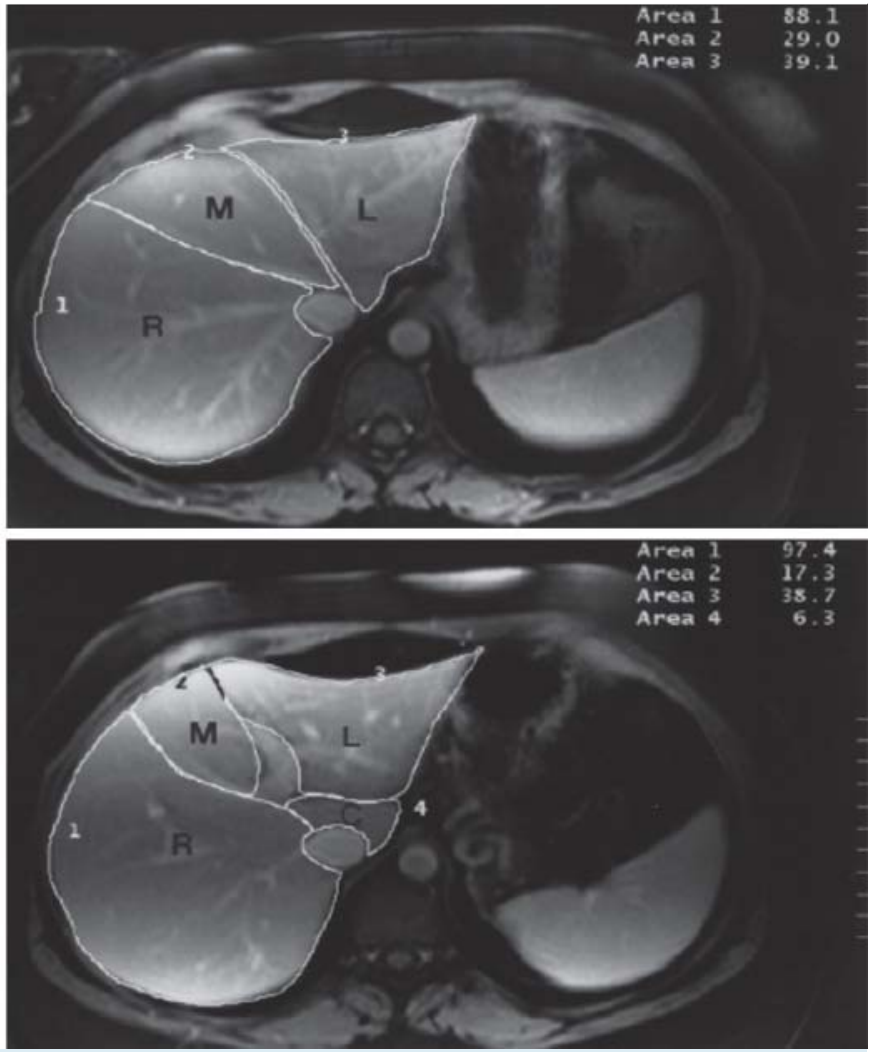

Abb. 1 Die zur Volumetrie verwendete Lebersegmentierungstechnik wird anhand axialer, kontrast-verstärkter und T1-gewichteter MR-Bilder mit Fettsättigung demonstriert. Die oberen Bilder entsprechen einem kranialeren Level als die unteren. Die Vena cava inferior (weißer Pfeil, Abb. links oben) und der linke intrahepatische Pfortaderast (schwarzer Pfeil, Abb. links unten) wurden von der Messung ausgeschlossen. Die Lebersegmente wurden nach Couinaud et al. definiert [14]. Die freihändig eingezeichneten Flächenkonturen umfassen den rechten Leberlappen ( $R$, Lebersegmente $V$, VI, VII, VIII), die links-lateralen Lebersegmente (L, Lebersegmente II und III), den Lobus caudatus (C, Lebersegment I) und die Lebersegmente IVa und IVb (M). Die Spende des rechten Leberlappen beinhaltete „R“, die der linkslateralen Segmente „L“ und die des linken Leberlappens „L“, „M“ und „C“ (C bei 3 der 5 Spendern). 


\section{Postoperative imaging}

Postoperative imaging data was available between 1 month and 84 months after transplantation, and was grouped according to the following time points: $1,3,6,12,24,36,48,60,72$, and 84 months. Image evaluation included volumetry of the liver remnant, and the detection and documentation of potential complications. Potential complications were particularly fluid collections (hematoma, bilioma, and abscess), dilatation and irregularities of the biliary system, and vascular obstruction or perfusion abnormalities. Documented postoperative complications were reevaluated in the follow-up examinations.

\section{Statistical analysis}

Statistical analyses were performed using the Graph Pad Prism software (version 6.0c; Graph Pad Software, La Jolla, CA, USA). The liver volumetry results are presented as absolute values [milliliters]. The ratio of the remaining liver volume and the preoperative total liver volume was calculated [percent]. Groups were compared with the student t-test after testing for normal distribution with the D'Agostino \& Pearson normality omnibus test. P-values $\leq 0.05$ were considered significant. Liver volumes were compared using Spearman rank correlation. The correlation was considered excellent for $r>0.8$, good for $r>0.6$, and moderate for $r>0.4$.

\section{Results}

$\nabla$

47 preoperative ( $\mathrm{CT}, \mathrm{n}=47$ ) and 89 follow-up imaging examinations ( $C T, n=46$; MRI, $n=43$ ) were evaluated in this study, giving a mean of 1.89 studies per patient (range, $1-6$ studies). The mean follow-up period was 22.4 months (range, 1 - 84 months).

\section{Preoperative imaging}

Donor anatomy

32 of the 47 donors had a normal arterial supply of the liver. In 4 patients, the left hepatic artery originated from the left gastric artery. In 7 patients the right hepatic artery and in 2 patients the common hepatic artery originated from the superior mesenteric artery (SMA). In another patient, the right hepatic artery originated from the gastroduodenal artery.

In one patient a trifurcation of the portal venous system was found.

Six patients had separate venous drainage of liver segment $\mathrm{V}$.

None of the patients showed stenoses of the hepatic arterial, portal venous, or venous vasculature. Arterial and late portal venous liver perfusion was regular in all patients.

In 9 patients, the right posterior hepatic duct drained directly into the left hepatic duct, and in 6 patients a biliary duct trifurcation was found. In two patients, the intrahepatic bile ducts were slightly enlarged due to the status post-cholecystectomy and cholecystolithiasis.

Four patients had a status post-cholecystectomy, three presented with cholecystolithiasis, and one with gall bladder sludge. Simple hepatic cysts of $>5 \mathrm{~mm}$ were found in 8 donors. A small hemangioma of less than $1 \mathrm{~cm}$ was detected in one patient.

\section{Preoperative liver volumes}

The donors were scheduled for right liver lobe (RLL) donation of segments V-VIII in 18 cases, and for left lateral section (LS; segment II and III) donation in 24 cases and left lobe (LLL; segments II-IV, $\mathrm{n}=2$; segments I-IV, $\mathrm{n}=3$ ) donation in 5 cases. RLL donors showed a mean total liver volume of $1,446.5 \mathrm{ml}( \pm 276.0)$, a mean volume of the segments V-VIII of $924.5 \mathrm{ml}( \pm 208.2)$, and a mean FLR volume of $522.0 \mathrm{ml}( \pm 144.0$; $36.1 \%)$. Donors of left liver tissue showed a mean total liver volume of $1,439.1 \mathrm{ml}$ $( \pm 249.8)$. In the subgroup of LS donation, the mean volume of segments II and III was $279.8 \mathrm{ml}( \pm 73.7)$, and the FLR volume was $1121.7 \mathrm{ml}$ ( $\pm 212.8 ; 79.9 \%)$. In the LLL donor subgroup, the mean volume of the liver segments (I-) II-IV was $438.4 \mathrm{ml}$ ( \pm 108.5$)$, and the FLR volume was $1181.5 \mathrm{ml}( \pm 279.5 ; 72.0 \%)$.

\section{Postoperative imaging}

Liver tissue explantation could be performed without mortality in all 47 donors.

\section{Postoperative liver volumes}

- Table 1 shows the pre- and postoperative volumetry results including the follow-up over a period of 84 months. After right liver lobe donation, the mean volume of the remaining liver tissue was $522.0 \mathrm{ml}( \pm 144.0 ; 36.1 \% ; \mathrm{n}=18)$. After left lateral section donation, the remaining liver volume was $1121.7 \mathrm{ml}( \pm 212.8 ; 79.9 \%$; $\mathrm{n}=24)$, and after left lobe donation it was $1181.5 \mathrm{ml}( \pm 279.5$; $72.0 \% ; n=5$ ). As shown in 0 Fig. 2, the remaining liver tissue started immediate regeneration in all donor subgroups. The volume of the remaining liver increased significantly within the first six months in most donors. At least $80 \%$ of the preoperative total liver volume was achieved in most donors. The strongest regenerative potential was detected in the subgroup after right lobe donation within the first three months. In the left lateral section subgroup, the remaining liver tissue exceeded the preoperative volume one month after donation. In all subgroups, the further regeneration proceeded slower, as the ascending slopes of the regeneration curves flattened between 3 and 12 months. The preoperative total liver volume of $100 \%$ was almost restored after 12 months in all subgroups. At later time points between 12 and 84 months, the regenerated liver volumes were comparable to the preoperative volume, and constantly maintained considering minimal variabilities $\left(\mathrm{p}_{36 \mathrm{mo}}=0.2155\right)$. The maximum volume of the liver remnant correlated well with the total preoperative volume in all donors using Spearman rank correlation analysis (॰ Fig. 3).

\section{Postoperative complications}

Liver tissue explantation was performed without severe complications in all donors. Minor postoperative complications were found in 4 patients ( $8.5 \%$ ). Three of these patients donated the right liver lobe, one the left lobe. In these patients, fluid collections in contact with the resection border were detected during follow-up and interpreted as biliomas. In three patients the collections had a maximum size of up to $4.0 \mathrm{~cm}$, in one patient the collection had a maximum diameter of $15.0 \mathrm{~cm}$. Signs of inflammation, such as peripheral contrast enhancement or gas inclusions, were not detected on these images. Therapeutic interventions were not necessary ( $\bullet$ Fig. 4 ). No other complications, especially no development of biliary dilation or irregularity, and no perfusion insufficiencies were found. Despite minor complications in these donors, the regenerative potential was not significantly reduced compared to the rest of the cohort ( $\bullet$ Fig. 2 ). Three of these patients achieved a remaining liver volume of $89 \% \pm 5.88$ during a maximum follow-up period of 24 months (donors without complications: $91.3 \% ; \mathrm{p}=0.3757$ ). One patient achieved a volume of $86 \%$ after 36 months. No complications occurred in left lateral section donors. 
Table 1 Liver volume in donors before and after live liver donation.

Tab. 1 Lebervolumen der Spender vor und nach Leberlebendspende.

\begin{tabular}{|c|c|c|c|c|c|c|c|c|c|c|c|c|c|c|c|c|c|}
\hline & & \multicolumn{5}{|c|}{ Right liver donors } & \multicolumn{5}{|c|}{ Left lateral section (II, III) } & \multicolumn{5}{|c|}{ Left lobe donors (II, III, IV) \pm I } \\
\hline & & & $\mathbf{n}$ & $\begin{array}{l}\text { Volume } \\
\text { [ml] }\end{array}$ & & $\%$ & & $\mathbf{n}$ & $\begin{array}{l}\text { Volume } \\
\text { [ml] }\end{array}$ & & $\%$ & & $\mathbf{n}$ & $\begin{array}{l}\text { Volume } \\
\text { [ml] }\end{array}$ & & $\%$ & \\
\hline $\begin{array}{l}\text { Preoperative } \\
\text { liver volume }\end{array}$ & Preop & & 18 & 1446.5 & \pm 276.0 & & & 24 & 1401.4 & \pm 279.7 & & & 5 & 1619.9 & \pm 438.4 & & \\
\hline $\begin{array}{l}\text { LTX graft } \\
\text { volume }\end{array}$ & & & 18 & 924.5 & \pm 208.2 & & & 24 & 279.7 & \pm 73.7 & & & 5 & 438.4 & \pm 108.5 & & \\
\hline FLR volume & 0 & & 18 & 522.0 & \pm 144.0 & 36.1 & \pm 7.9 & 24 & 1121.7 & \pm 212.8 & 79.9 & \pm 4.9 & 5 & 1181.5 & \pm 279.5 & 72.0 & \pm 8.3 \\
\hline \multirow{10}{*}{$\begin{array}{l}\text { Volume of } \\
\text { liver remnant - } \\
\text { follow-Up } \\
\text { [months post } \\
\text { donation] }\end{array}$} & 1 & \pm 0.00 & 4 & 801.8 & \pm 176.6 & 54.8 & \pm 16.4 & 2 & 1333.4 & \pm 400.5 & 120.5 & \pm 13.9 & 0 & & & & \\
\hline & 3 & \pm 0.54 & 6 & 1236.4 & \pm 116.2 & 80.8 & \pm 7.5 & 3 & 1252.3 & \pm 281.5 & 88.9 & \pm 16.0 & 1 & 1025.0 & \pm 0.0 & 72.8 & \pm 0.0 \\
\hline & 6 & \pm 0.45 & 6 & 1286.9 & \pm 230.3 & 83.8 & \pm 5.0 & 0 & & & & & 1 & 1976.0 & \pm 0.0 & 96.4 & \pm 0.0 \\
\hline & 12 & \pm 1.33 & 11 & 1246.6 & \pm 251.8 & 87.3 & \pm 11.8 & 18 & 1331.5 & \pm 222.3 & 95.0 & \pm 11.6 & 2 & 1190.5 & \pm 90.5 & 80.1 & \pm 2.0 \\
\hline & 24 & \pm 1.67 & 2 & 1423.9 & \pm 277.9 & 94.0 & \pm 4.7 & 4 & 1346.5 & \pm 198.0 & 101.6 & \pm 11.9 & 1 & 1405.9 & \pm 0.0 & 90.0 & \pm 0.0 \\
\hline & 36 & \pm 2.68 & 3 & 1379.5 & \pm 198.5 & 89.1 & \pm 6.1 & 7 & 1442.5 & \pm 169.4 & 101.9 & \pm 8.8 & 2 & 1760.5 & \pm 419.5 & 96.1 & \pm 10.2 \\
\hline & 48 & \pm 2.56 & 2 & 1748.3 & \pm 83.4 & 106.5 & \pm 0.3 & 4 & 1183.0 & \pm 103.9 & 86.3 & \pm 8.1 & 1 & 2159.5 & \pm 0.0 & 105.3 & \pm 0.0 \\
\hline & 60 & \pm 3.25 & 1 & 1916.5 & \pm 0.0 & 111.2 & \pm 0.0 & 1 & 1411.2 & \pm 0.0 & 101.7 & \pm 0.0 & 3 & 1581.2 & \pm 336.6 & 92.8 & \pm 16.5 \\
\hline & 72 & \pm 1.00 & 0 & & & & & 1 & 1296.3 & \pm 0.0 & 93.4 & \pm 0.0 & 1 & 1724.7 & \pm 0.0 & 105.6 & \pm 0.0 \\
\hline & 84 & \pm 0.50 & 0 & & & & & 1 & 1565.8 & \pm 0.0 & 79.7 & \pm 0.0 & 1 & 1556.6 & \pm 0.0 & 95.3 & \pm 0.0 \\
\hline
\end{tabular}

LTX: liver transplantation; FLR: future liver remnant; n: number of donors.

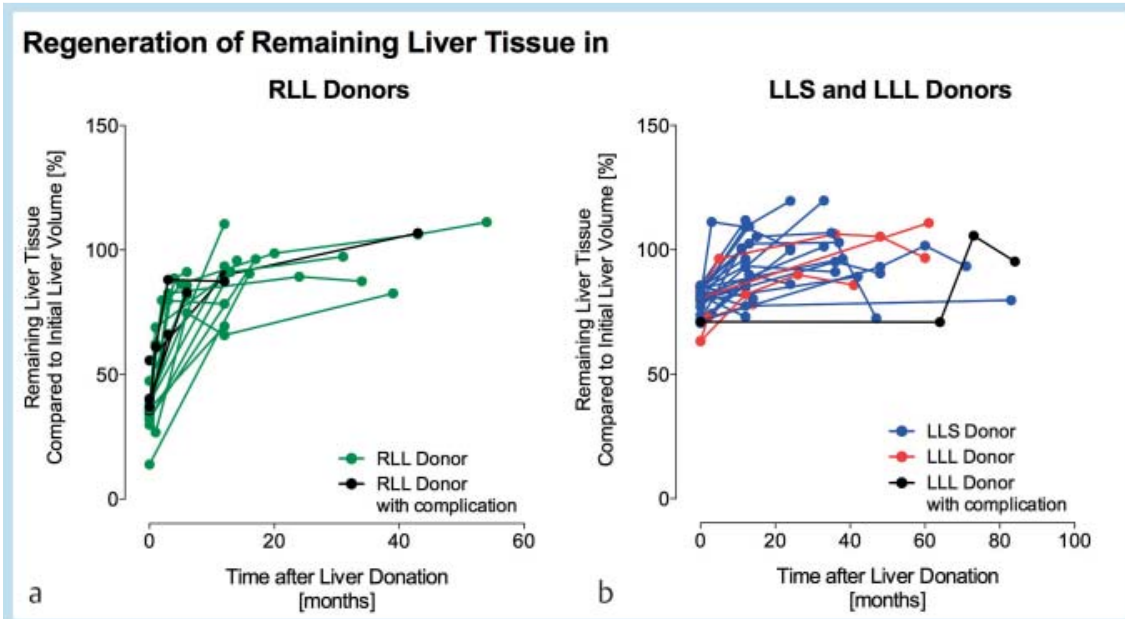

Fig. 2 Regeneration of remaining liver tissue of each donor after explantation of the right liver lobe (RLL, $\mathbf{a} ; n=18$ ), the left lateral section (LLS, $\mathbf{b}$; $n=24)$, and the left liver lobe (LLL, $\mathbf{b} ; n=5)$. At the initial time point ( 0 months), the fraction of remaining liver tissue is presented in comparison to the total preoperative liver volume (100\%). Donors with minor postoperative complications, such as seroma or bilioma, are indicated (black dots).
Abb.2 Regeneration des verbliebenen Lebergewebes der einzelnen Spender nach Explantation des rechten Leberlappens (RLL, a; $n=18$ ), der links lateralen Segmente (LLS, $\mathbf{b} ; \mathrm{n}=24)$ und des linken Leberlappens (LLL, b; $\mathbf{n}=5$ ). Zum initalen Kontrollzeitpunkt (0 Monate) wird der Anteil des verbliebenen Lebergewebes im Vergleich zum totalen präoperativen Lebervolumen $(100 \%)$ dargestellt. Die Spender mit leichtgradigen postoperativen Komplikationen, wie bspw. Serom oder Biliom, wurden gesondert markiert (schwarze Diagrampunkte).

\section{Discussion}

$\nabla$

CT and MRI are valuable tools in the preoperative evaluation and follow-up of donors after LDLT [15-18]. Regeneration of remaining liver tissue after donation has been evaluated with CT or MRI in several short-term studies, as presented in 0 Table 2 [10, 19 26]. The studies demonstrated the highly regenerative potential of liver remnants in donors between a few days up to 12 months after surgery. Despite these promising observations, long-term follow-up results regarding liver volume regeneration and maintenance are still lacking. For promoting LDLT, an increasingly demanded therapy option, ensuring donor safety is of maximum importance. Long-term observations of the liver remnant volume - as a potential imaging biomarker for liver regeneration - and the course of complications in donors are desired for proving that LDTL is not a severely compromising procedure and does not involve severe complications. Our study collective is unique, since liver regeneration was documented during a long follow-up period of up to 84 months (mean 24 months).

Concordantly to previous studies, we found that remaining liver tissue was highly regenerative in the early period after donation $[7,9,10]$. The liver volume before donation was almost restored after 6 months. Interestingly, the regenerated volumes in right lobe donors were almost as quickly restored as in the left lobe, 
or left lateral section donors, although the resected graft volumes were greater in right lobe donors. This demonstrates the highly regenerative potential of liver tissue, which may be independent from the amount of tissue loss in these ranges of tissue harvesting. Nakakami et al. have shown that the regenerative potential correlates with the volume of the explanted tissue volume [19]. The influencing factors of liver regeneration are still not fully un-

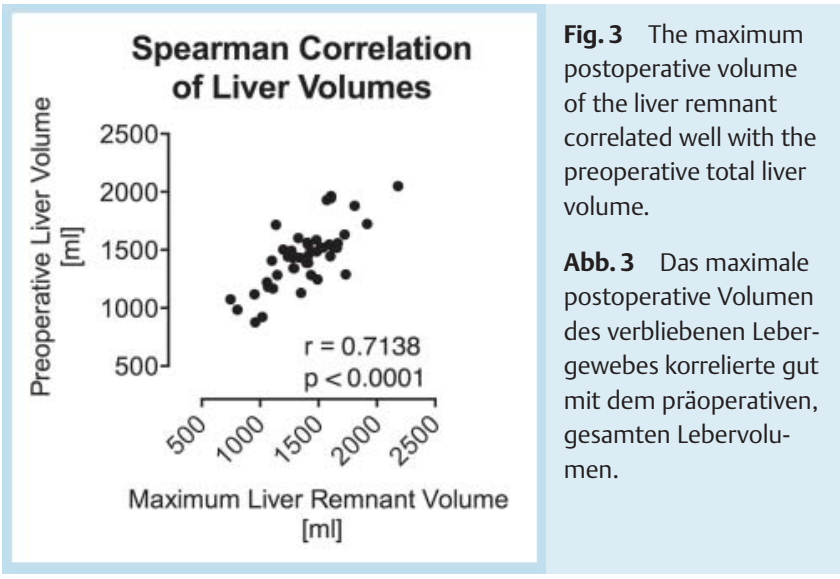

derstood. Identified factors, which compromise liver regeneration are liver steatosis and donor age [10]. Growth factors (e.g. EGF, HGF) and cytokines (TNF-alpha) stimulate growth of liver tissue via autocrine and endocrine pathways, and therefore play an important role in liver regeneration [27]. The regulation of this growth process and factors that stop it have not yet been completely identified.

We observed that the rapid initial regeneration of liver tissue slows as the remnant volume approaches the original volume before donation. The original liver dimensions were more or less restored in most donors, as the maximum liver remnant volumes correlated well with the preoperative total liver volumes. Our evaluation shows that after six months, the regenerated liver volume was constantly maintained with volume fractions of at least $80 \%$ of the original liver volume during the total follow-up period. Nevertheless, several donors showed remnant volumes of $>100 \%$ of the preoperative liver volumes during follow-up. While tissue regeneration begins immediately at a cellular level, the process of remodeling has been assumed to continue for longer time periods [28].

Fluid collections, interpreted as bilioma, were postoperatively detected in 4 donors (8.5\%) adjacent to the resection margin. In these donors, the total right or left liver lobe was explanted. In comparison to the left lateral section, RLL and LLL donation in-
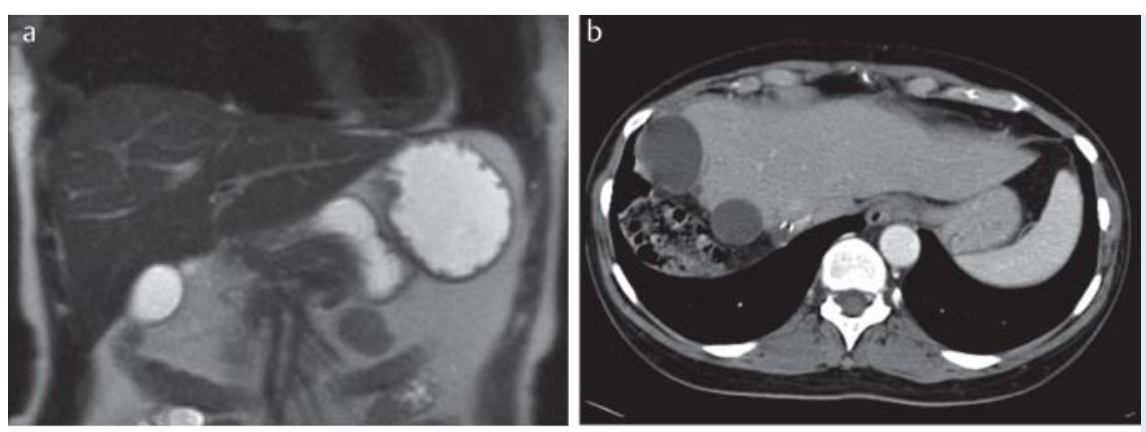

Fig. 4 MR and CT images of a donor before (A, MRI T2w coronal image), 6 months (B, CT axial MPR image), and 12 months ( $C+D, M R I T 2 w$ coronal and T1w post-contrast axial image) after right lobe liver donation of segment V-VIII. Despite two small fluid collections at the right resection margin, the volume of the remaining left lobe was rapidly increased and maintained.

Abb. 4 MRT und CT Bilder eines Spenders vor (A, MRT T2w coronar) sowie 6 (B, CT axiale MPR) und 12 Monate (C+D, MRT T2w coronar und T1w nach
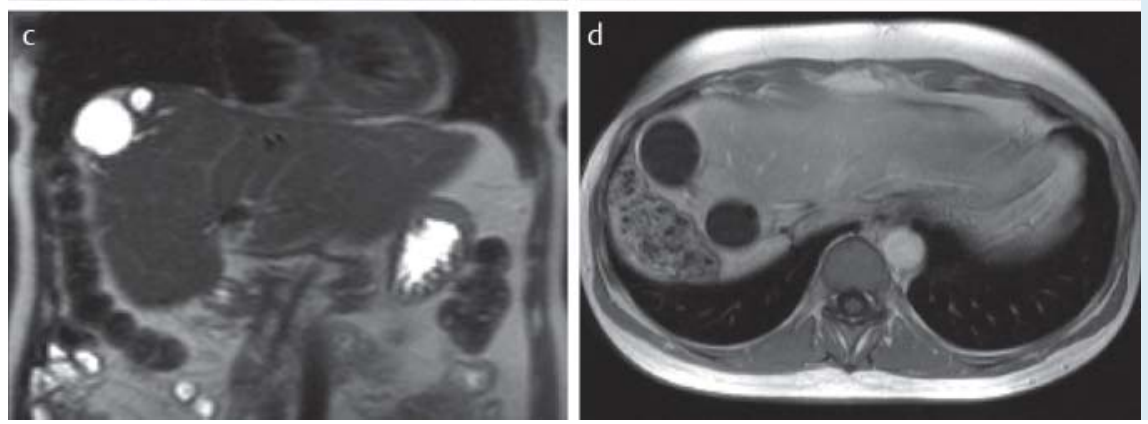
Kontrastmittelgabe axial) nach Spende der rechtsseitigen Segmente V-VIII. Trotz zweier kleiner Flüssigkeitskollektionen am rechtsseitigen Resektionsrand kam es zu einer zügen und andauernden Regeneration des verbliebenen Leberlappens.

\begin{tabular}{|c|c|c|c|c|c|}
\hline Author & Patients & Techn. & Donation & Follow-up & Regeneration in total \\
\hline Nakagami at al., 1999 & 37 & $\mathrm{CT} / \mathrm{MRI}$ & LLD, LSD & $14,21,28 d$ & LSD - 28d: $82 \% ;$ LLD - 28d: $80 \%$ \\
\hline Marcos et al., 2000 & 31 & MRI & RLD & $60 d$ & 7d: $101 \% ; 60 d: 144 \% 1$ \\
\hline Pascher et al., 2002 & 43 & $\mathrm{CT} / \mathrm{MRI}$ & RLD & $12 \mathrm{mo}$ & $6 \mathrm{mo}: 72 \%, 12 \mathrm{mo}: 85 \%$ \\
\hline Kwon et al., 2003 & 41 & $\mathrm{CT}$ & RLD & $30 d$ & 30d: $88.5 \%$ \\
\hline Pomfret et al., 2003 & 51 & $\mathrm{CT}$ & RLD & $12 \mathrm{mo}$ & 7d: $49 \% ; 12$ mo: $83 \%$ \\
\hline Nadalin et al., 2004 & 27 & MRI & RLD & $360 d$ & 10d: $88 \% ; 360 d: 83 \%$ \\
\hline Ibrahim at al., 2005 & 109 & CT & RLD, LLD & $6 \mathrm{mo}$ & RLD - 6 mo: $90 \%$; LLD - 6 mo: $92 \%$ \\
\hline Paluszkiewicz et al., 2008 & 100 & CT & LLD, LSD & $12 \mathrm{mo}$ & LSD - 12 mo: $10 \%$, LLD - 12 mo: $139 \% 1$ \\
\hline Haga et al., 2008 & 87 & CT & RLD, LLD, LSD & $12 \mathrm{mo}$ & RLD - 12 mo: $89 \%$; LSD+LLD - $12 \mathrm{mo:} 90 \%$ \\
\hline
\end{tabular}

Table 2 Existing studies concerning the regeneration of the liver remnant in living liver donors assessed by CT and MRI

Tab. 2 Bisherige Studien zur Evaluation der Lebervolumenregeneration bei Leberlebendspendern mittels CT und MRT.

RLD: right lobe donation, LSD: left lateral section, LLD: left lobe donation, d: days; mo: months

${ }^{1}$ fraction of postoperative remnant volume 
volves a larger bare resection border. This may explain why no biliomas were detected in left lateral section donors, whereas bare areas are smaller due to the separation of segments by the falciform ligament. In donors with bilioma, no therapeutic interventions were necessary. Furthermore, the regenerative potential may not have been significantly reduced. None of the donors had severe complications and all transplantations were performed without donor mortality. Our observations are comparable to data from the Japanese Liver Transplantation society, which reported a complication rate of $8.4 \%$ in a collective of more than 3500 donors [29]. Common complications such as biliary sclerosis, perfusion defects, intrahepatic cholestasis, hematoma, or abscesses were not found in our collective [6]. A low complication rate is essential for donors to regain life quality and may provide a convincing argument for potential donors in the decision process. A Japanese study group recently published results of a health-related quality of life survey demonstrating that the quality of life in donors was superior to the normal population in the long term. They also demonstrated that surgery-related complications did not significantly reduce the quality of life, and specified the number of months until recovery to the preoperative health status and other symptoms that prolonged the rehabilitation of the donors [30].

Our study has several limitations. Although the study was conducted at a high volume liver transplant center, only a small number of donors were available for pre- and post-transplantation imaging and follow-up. The locally offered follow-up process includes repeated consultations within the first 12 months and at least one MRI or CT study after transplantation. Due to a high number of non-resident donors, many potential study participants were lost during the follow-up, or incomplete donor data were available. For the same reason, we refrained from a complete follow-up evaluation including a correlation of liver function and clinical data. Our study collective included slightly more donors of liver tissue from the left liver lobe (62\%) owing to smaller transplant organ sizes needed for children. Methodological limitations are the inclusion of imaging studies acquired with different imaging modalities, such as CT and MRI, and the slice thickness of $5 \mathrm{~mm}$. CT and MRI scans have been indicated for routine follow-up by referring liver transplant surgeons according to potential contraindications and the physician's preference. Both CT and MRI volumetry have been attributed to the overestimation of intraoperative organ volume. The degree of overestimation may be higher using MR volumetry due to longer acquisition times, partial volume effects, and blurring artifacts [31]. Thus, absolute volumetric measurements of this study may be constantly greater than intraoperative organ volumes, and may differ between CT and MRI studies. Furthermore, slice thickness affects the results of CT and MR volumetries. Reiner et al. have shown that liver volumes decrease with increasing slice thickness [32]. We used a slice thickness of $5 \mathrm{~mm}$ for uniform comparison of all imaging studies, which had been acquired with different modalities and scanners.

\section{Conclusion \\ $\nabla$}

Imaging follow-up of donors after LDLT demonstrated rapid regeneration of liver remnant volumes within the first 6 months. Restored liver remnant volumes were maintained during the long-term follow-up period of up to 84 months. Early minor complications were detected in $8.5 \%$ of donors; no late complications were detected. Rapid regeneration and long-term maintenance of liver remnant volumes and the absence of severe or late complications are important observations in the assessment of donor safety.

\section{References}

1 Olsen SK, Brown RS. Live donor liver transplantation: current status. Curr Gastroenterol Rep 2008; 10: 36-42

2 Neumann UP, Neuhaus P, Schmeding M. Living donor liver transplantation in adults. Chirurg 2010; 81: 804-806-12

3 Walter J, Burdelski M, Bröring DC. Chances and risks in living donor liver transplantation. Dtsch Arztebl Int 2008; 105: 101-107

4 Brown RS. Live donors in liver transplantation. Gastroenterology 2008; 134: $1802-1813$

5 Chan SC, Fan ST, Liu CL et al. Working up donors for high-urgency and elective adult-to-adult live donor liver transplantation. Liver Transpl 2007; 13: 509-515

6 Middleton PF, Duffield M, Lynch SV et al. Living donor liver transplantation-adult donor outcomes: a systematic review. Liver Transpl 2006; 12: $24-30$

7 Zappa M, Dondero F, Sibert A et al. Liver regeneration at day 7 after right hepatectomy: global and segmental volumetric analysis by using CT. Radiology 2009; 252: 426-432

8 Maetani $Y$, Itoh $\mathrm{K}$, Egawa $\mathrm{H}$ et al. Factors influencing liver regeneration following living-donor liver transplantation of the right hepatic lobe. Transplantation 2003; 75: 97-102

9 Kamel IR, Erbay N, Warmbrand G et al. Liver regeneration after living adult right lobe transplantation. Abdom Imaging 2003; 28: 53-57

10 Paluszkiewicz R, Zieniewicz K, Kalinowski P et al. Liver regeneration in 120 consecutive living-related liver donors. Transplant Proc 2009; 41: $2981-2984$

11 Shimada M, Matsumata T, Maeda T et al. Hepatic regeneration following right lobectomy: estimation of regenerative capacity. Surg. Today 1994; $24: 44-48$

12 Leelaudomlipi S, Sugawara Y, Kaneko J et al. Volumetric analysis of liver segments in 155 living donors. Liver Transpl 2002; 8: 612-614

13 Rosset $A$, Spadola $L$, Pysher $L$ et al. Informatics in radiology (infoRAD): navigating the fifth dimension: innovative interface for multidimensional multimodality image navigation. Radiographics 2006; 26: $299-308$

14 Couinaud C. Definition of hepatic anatomical regions and their value during hepatectomy. Chirurgie 1980; 106: 103-108

$15 \mathrm{Krumm}$ P, Schraml C, Bretschneider C et al. Depiction of variants of the portal confluence venous system using multidetector row CT: analysis of 916 cases. Fortschr Röntgenstr 2011; 183: 1123-1129

16 Bitschnau S, Oberholzer K, Kreitner KF et al. CT-angiography with a 16row CT scanner for perioperative evaluation of the hepatic arteries. Fortschr Röntgenstr 2004; 176: 1634 - 1640

17 Krupski G, Rogiers X, Nicolas V et al. The significance of the arterial vascular supply of segment IV in living liver donation. Fortschr Röntgenstr 1997; 167: 32 - 36

18 Lemke A-J, Brinkmann MJ, Pascher A et al. Accuracy of the CT-estimated weight of the right hepatic lobe prior to living related liver donation (LRLD) for predicting the intraoperatively measured weight of the graft. Fortschr Röntgenstr 2003; 175: $1232-1238$

19 Nakagami $M$, Morimoto $T$, Itoh $K$ et al. Patterns of restoration of remnant liver volume after graft harvesting in donors for living related liver transplantation. Transplant Proc 1998; 30: 195-199

20 Marcos A, Fisher RA, Ham JM et al. Liver regeneration and function in donor and recipient after right lobe adult to adult living donor liver transplantation. Transplantation 2000; 69: 1375-1379

21 Pascher A, Sauer IM, Walter $M$ et al. Donor evaluation, donor risks, donor outcome, and donor quality of life in adult-to-adult living donor liver transplantation. Liver Transpl 2002; 8: 829-837

22 Kwon KH, Kim YW, Kim SI et al. Postoperative liver regeneration and complication in live liver donor after partial hepatectomy for living donor liver transplantation. Yonsei Med J 2003; 44: 1069-1077

23 Pomfret EA. Early and late complications in the right-lobe adult living donor. Liver Transpl 2003; 9: S45 -9

24 Nadalin S, Testa G, Malagó M et al. Volumetric and functional recovery of the liver after right hepatectomy for living donation. Liver Transpl 2004; 10: $1024-1029$ 
25 Ibrahim S, Chen C-L, Wang C-C et al. Liver regeneration and splenic enlargement in donors after living-donor liver transplantation. World J Surg 2005; 29: 1658 - 1666

26 Haga J, Shimazu M, Wakabayashi G et al. Liver regeneration in donors and adult recipients after living donor liver transplantation. Liver Transpl 2008; 14: 1718-1724

27 Böhm F, Köhler UA, Speicher T et al. Regulation of liver regeneration by growth factors and cytokines. EMBO Mol Med 2010; 2: 294-305

28 Florman S, Miller CM. Live donor liver transplantation. Liver Transpl 2006; 12: 499-510

29 Kaido T, Uemoto S. Does living donation have advantages over deceased donation in liver transplantation? Journal of Gastroenterology and Hepatology 2010; 25: 1598 - 1603
30 Takada Y, Suzukamo Y, Oike F et al. Long-term quality of life of donors after living donor liver transplantation. Liver Transpl 2012; 18: 1343 1352

31 Karlo C, Reiner CS, Stolzmann P et al. CT- and MRI-based volumetry of resected liver specimen: comparison to intraoperative volume and weight measurements and calculation of conversion factors. Eur J Radiol 2010; 75: e107-e111

32 Reiner CS, Karlo C, Petrowsky H et al. Preoperative liver volumetry: how does the slice thickness influence the multidetector computed tomography- and magnetic resonance-liver volume measurements? J Comput Assist Tomogr 2009; 33: 390 - 397 